\title{
Interest Rates Determinants in Demonetised Economy
}

Dr Aswatha Narayana, Assistant Professor, GFGC , KR Puram, aswathn@gmail.com

Prof. Rajini.T.V, Research Scholar\& Assistant professor, GFGC,Deveanahalli, rajini2125@gmail.com

\begin{abstract}
The main focus of this research study is to look into the determinants of interest rates in India post demonetisation. India entered the demonetised phase in November of 2016, and since then the economy has slugged down a lot. This study aims at studying the three explanatory variables; inflation rate, money supply and monetary policy rate in order to evaluate their impact on the trend of interest rate. It is a general belief that the variables have a relationship, in so much that they affect the interest rates. The RBI takes measures so as to create an investment-friendly rate of interest, which is necessary for promoting economic growth. This should be addressed as infrastructural expenditure incurred by banks are passed to borrowers through interest rate.
\end{abstract}

Keywords: Interest rate, Demonetisation, Monetary policy rate and Economic growth

\section{INTRODUCTION}

Over the years, interest rate in India has been managed by the monetary authority as a monetary and credit policy tool aimed at inflation control, investment inducement and economic growth. Interest rate is the price paid for the use of money. It is the opportunity cost of borrowing money from a lender. It is an important economic price determined by various factors and useful in gauging financial market conditions. The direction and magnitude of changes in market interest rate are primarily important to policy makers as it determines the growth path of the economy. The role and effect of interest rate is possible due to the link between the financial sector and real sector of the economy. For example, the lending rate which translates into cost of capital has direct implications for investment. The behaviour of interest rate determines investment activities and hence economic growth of a country. Banks as intermediaries mobilize funds from surplus spending units to deficit spending units of theeconomy through deposit acceptance and in turn, channel them into productive economic activities. The extent to which this is done lies on the interest rate which in turn determines economic growth (Uchendu, 1993).

According to Omole\&Falokun, (1999), interest rate policy is among the emerging issues incurrent economic policy in India. In view of the role it is expected to play in a deregulated economy by inducing savings which can be channel to investment and thereby increasing employment, output and efficient financial resource utilization. Also, interest rates can have as ubstantial influence on the rate and pattern of economic growth by influencing the volume and disposition of saving as well as the volume and productivity of investment (Tayor, 2004).

Oresotu (1992) explained the functions of interest rates in which people decide whether to borrow, invest, save and/or consume as:

- A consumption deferment due to incentives gotten from financial assets by savers.

- Interest rate as a component of cost of capital affects the demand for and allocation of loanable fund.

- Domestic interest rate in conjunction with the 
rate of return on foreign financial assets and goods are hedged against inflation.

Interest rate in India could be examined under two regimes; the regulated period characterized by a fixed rate and the demonetised period where interest rate is freely determined by market forces of demand and supply.

Before the demonetised era, the monetary authority (RBI) relied on the use of direct control mechanism to fix interest rate and other banking charges with periodic adjustments depending on the government sectoral priorities. This was done to obtain social optimum resource allocation, promote orderly growth of the financial market and combat inflation. In adjusting interest rate according to sectoral priorities, the government aimed at direct financial resources at concessionary low interest rate to the favored sectors for possible increase in productivity and subsequently, economic growth (Udoka, 2000). For instance, in 1984, banks were instructed to lend to agricultural sector at $7 \%$. This had serious implication for the economy as the period was considered a financial repression period (McKinnon \& Shaw) where government regulations, laws and other restrictions prevented financial intermediaries from functioning at full capacity. The prevailing rates at the time were unable to keep pace with inflation thereby resulting in negative real interest rates. This led to the demand for credit exceeding savings, inefficient resource allocation and pricing, starvation of funds to essential sectors of the economy and under development of the financial market (Obute, Asor\&Idoko 2012).

In July 1987, the RBI deregulated interest rate. Interest rate under this policy was to be determined by market forces. This was due to the economic disturbances experienced in the economy in the early 1980s due to world oil price fall and the financial repression. The objective of deregulating the interest rate was to promote investment through the linkage between interest rate and investment. Specifically, the RBI maintained a flexible interest rate stance, anchored on adjustment of minimum rediscount rate complemented by cash reserve and the use of moral suasion (RBI 2005). It is however observed that banks lending rate rose while deposit rates were low. This resulted in a wide gap between both rates threatening domestic price stability, savings and credit availability to the real sector of the economy. The monetary rediscounted rate (MRR) has been replaced with the monetary policy rate (MPR).

In 1994-1995, the fixed interest rate was reintroduced to check the persistent increase in interest rate. The surge in the interest rate was high such that lending rate reached $21 \%$ while deposit rate was $13.6 \%$, discouraged investment.

The re-introduction of fixed interest rate was due to:

Inflation rate was as high as $72.8 \%$ in 1995

High fiscal deficit of the Federal Government

Technical insolvency of many banks resulting in distress borrowing from the banking and pervasive defaults in the money market and speculative attack on the foreign exchange arising from excess borrowing from the banking sector, (RBI, 2005).

Persistent high inflation rate became a major challenge to the monetary authorities in achieving economic stability.

There were wide variations and unnecessarily high interest rate under the complete demonetised of interest rate. Deposits were once again set at $12 \%$ $15 \%$ per annum, while a ceiling of $21 \%$ per annum was fixed for lending (RBI, 2006). The fixing of interest rate introduced in 1994 was retained in 1995 with a minor modification to allow for flexibility. This situation remained until 1996 when interest rate was deregulated again with the bank given the freedom to determine interest rate with their customers. The $\mathrm{RBI}$ retained the discretionary power to intervene to ensure orderly development in interest rate.

\section{Statement of the Problem}

The primary role of interest rate is to help in the mobilization of financial resources and to ensure the efficient utilization of such resources in the production, promotion of economic growth and 
development. It thus affects the level of consumption on the one hand and the level of investment on the other hand, which in turn affects growth in the real world.

The performance of the economy is thus, linked with the level of interest rate as it exerts pressure on the stock market capitalization rate, manufacturing sector performance, foreign exchange rate etc (Adebiyi\&Babatope-Obasa 2004). High interest rate impedes economic activities and slow down growth. It discourages borrowing for investment thereby hampering output and affecting GDP. It adversely affects exports and threatens widespread problem in the international banking system.

With the experience of the interest rate in India and its direct/indirect impact on the economy and with the operation of a deregulated economy in India, it becomes important to check for variables that determines the level and direction of interest rate under deregulated period.

\section{Objective of the Study}

The major objective of this study is to investigate the determinants of interest rate in India under the demonetised period.

\section{The Research Hypothesis}

The research will be guided by the following hypothesis:

Ho: There exist no significant relationship between interest rate and the determining variables selected.

\section{Theoretical Review}

Various theories of interest rates provide variables which determine interest rates. These theories differ in opinion dues to the fact that some theorists see interest rates determination as a monetary phenomenon while others, as a real phenomenon.

The neo-classical opined that interest rate is determined by the demand and supply of loanable funds. The demand for loanable fund by government, businessmen and consumers for the purpose of investment, hoarding and consumption depends on the expected rate of profit as compared with the rate of interest and satisfaction for consumers. This demand is met by past savings or through dis-saving and are interest elastic. They are higher with higher interest rate. The loanable fund regards the rate of interest as a function of four variables: savings, investment, the desire to hoard and the money supply (Jhingan, 1990). However, the Keynesian theory of interest rate was of the view that the rate of interest is purely a monetary phenomenon and is determined by the demand and supply of money (Ahuja, 2013), analogous of liquidity preference theory. The liquidity preference is the premium that wealth holders demand in exchange for ready money or bank deposits. It refers to the relationship between the quantities of money the public wishes to hold and the interest rate, the higher the liquidity preference, the higher the interest rate to be paid for parting with liquid assets and vice versa.

\section{Empirical Review}

Using a time series technique, Gul and Ekinci (2006) studied the relationship between nominal interest rates and inflation using high-frequency data of nominal interest rate and inflation for Turkey. They concluded that there exist a long run relationship between nominal interest rates and inflation. The results, however, indicate that a causal relationship occurs only in one direction running from nominal interest rate to inflation without the reverse causation.

Dlamini et al. (2001) concluded in his study that interest rates seem to play no significant role in the inflation function for Swaziland. This he explained is because in most developing countries, interest rates tend to be inoperative due to a non-existence of a well-developed money market and the fact that interest rates do not necessarily reflect money market conditions but are institutionally pegged. It is, therefore, difficult to ascertain whether interest rates affect prices or not.

An empirical analysis for Pakistan was conducted by Mukhtar and Zakaria (2007) regarding budget deficit and interest rates. They empirically examined longrun relationship between nominal interest rate and budget deficits for Pakistan using quarterly time- 
series data for the period 1960 to 2005 . They tested the "crowding-out" view against the "Ricardian deficit neutrality" alternative. Regression result showed that budget deficit do not have significant effect on nominal interest rates. These result revealed the existence of the Ricardian Deficit Neutrality in Pakistan, while budget deficit GDP ratio has significant positive impact on nominal interest rates.

\section{METHOD OF STUDY AND MODEL SPECIFICATION}

The determinants of interest rate in India are examined by estimating a linear regression model. Studies have identified various factors that determine interest rate. In this work, we specified a model with a dependent variable (interest rate) and three explanatory variables inflation rate, monetary policy rate and money supply, so as to investigate the extent to which these explanatory variables determine the level of interest rate in the economy under the regulated period. Thus,

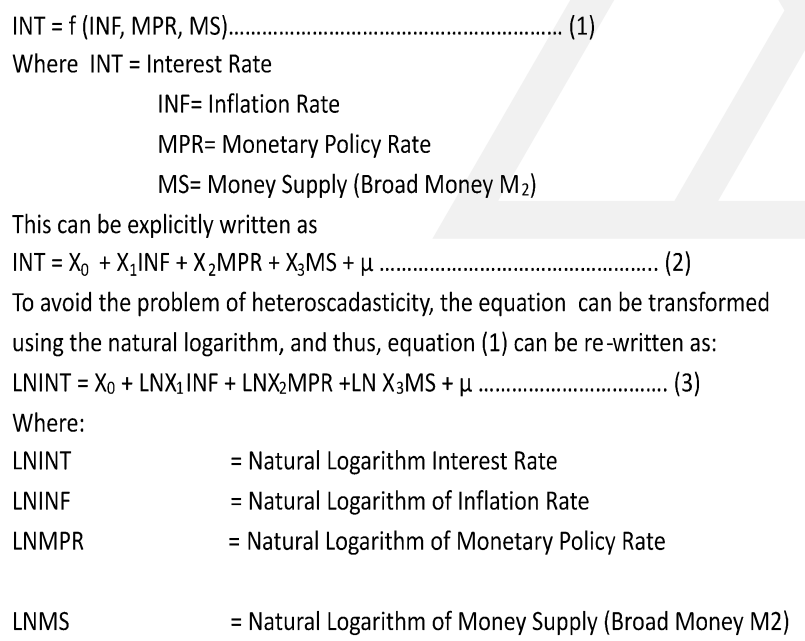

\section{Expectations}

- Based on economic theory, lowering interest rate, will encourage borrowing. There will be much money in circulation. This increases the spending power of the public and as such, there will be an accompanying increase in price of goods and services (inflation). Thus there is expected to be, a negative relationship between INT and INF and the coefficient of INF is expected to be negative $\mathrm{X}_{1}<0$.

- There is expected to be a positive relationship between INT and MPR. Monetary policy rate is the rate at which the $\mathrm{RBI}$ lend to the commercial banks. Since banks cannot afford to lend lower than the monetary policy rate, an increase in MPR will be accompanied by an increase in INT. Thus coefficient of MPR is expected to be positive. $\mathrm{X}_{2}>0$.

- An inverse relationship is expected between INT and MS. Lowering interest rate, encourages borrowing. This increases the money supply in the economy which in turn is expected to increase purchasing power thereby increasing demand for outputs which in turn boost investment. The coefficient of MS is expected to be negative. $X_{3}<0$.

The use of the Ordinary Least Square method is employed in this analysis. The unit root test using the Augmented Dickey Fuller test (ADF) will be employed to check for stationarity. The Johansen Cointegration test will also be employed to confirm if the series are co-integrated while the Error Correction Model (ECM) technique will be employed to derive parsimonious models used for further analysis. (Onuchuku\&Adoghor 1999).

\section{DATA ANALYSIS AND PRESENTATION OF RESULTS}

Having tested the null hypothesis ( $\mathrm{Ho}$ ) that there exist no significant relationship between interest rate and the selected independent variables, we present the result gotten. The study employed secondary data gotten from various sources including the Reserve Bank of India Statistical bulletin 2017.

\section{Stationarity Test}

In order to avoid spurious results, the unit root test using the Augumented Dickey Fuller test (ADF) for testing stationarity of time series data was employed. Box and Henkins (1976) posited that non-stationary time series in levels may be made stationary after differencing $d$ times. If the series is said to be 
integratedof order $\mathrm{d}(\mathrm{I}(\mathrm{d}))$, it attained stationarity after differencing $d$ times. This situation arises if the variable did not achieve stationarity at the first differencing known as levels denoted as I(0). This is the situation with the variables employed in this study.

The ADF test statistic seen in Table 1 below showed that all time series data are achieved stationarity at first differencing at $5 \%, 1 \%$ and $10 \%$ level of significance. At absolute value, the values of the $t$ statistics were greater than the critical values at $5 \%$, $1 \%$ and $10 \%$ respectively.

\section{Table 1: Augmented Dickey-Fuller test statistic}

\begin{tabular}{|l|l|l|l|l|l|l|}
\hline & $\begin{array}{l}\mathrm{t}- \\
\text { statistic }\end{array}$ & $\begin{array}{l}\text { Critical } \\
\text { values } \\
1 \%\end{array}$ & $\begin{array}{l}\text { Critical } \\
\text { values } \\
5 \%\end{array}$ & $\begin{array}{l}\text { Critical } \\
\text { values } \\
10 \%\end{array}$ & Prob. & $\begin{array}{l}\text { Order } \\
\text { of Inte } \\
\text { gration }\end{array}$ \\
\hline (LNINT) & -4.704398 & -3.7343 & -2.9907 & -2.6348 & 0.000001 & $\mathrm{I}(1)$ \\
\hline $\mathrm{D}$ (LNINF) & -5.815895 & -3.7343 & --2.9907 & -2.6348 & 0.000023 & $\mathrm{I}(1)$ \\
\hline $\mathrm{D}$ (LNMS) & -5.110776 & -3.7343 & --2.9907 & -2.6348 & 0.000001 & $\mathrm{I}(1)$ \\
\hline $\mathrm{D}$ (LNMPR) & -4.526503 & -3.7343 & --2.9907 & -2.6348 & 0.000039 & $\mathrm{I}(1)$ \\
\hline
\end{tabular}

\section{Co-integration Test}

The Johansen co-integration analysis was used to determine if there exists a long-run equilibrium relationship among variables under study. It revealed that 2 variables are co-integrated at $5 \%$ critical value. The likelihood ratio of $67.62467 \& 36.44791$ are all greater than the critical value of $53.12 \& 34.91$. We therefore reject the null hypothesis and conclude that there exist at least one co-integrating relationship and as such, long run equilibrium exists among the variables.

\section{Table 2: Johansen Cointegration Test}

\begin{tabular}{|l|l|l|l|l|}
\hline & Likelihood & 5 Percent & 1 Percent & $\begin{array}{l}\text { Hypothe } \\
\text { sized }\end{array}$ \\
\hline Eigenvalue & Ratio & $\begin{array}{l}\text { Critical } \\
\text { Value }\end{array}$ & $\begin{array}{l}\text { Critical } \\
\text { Value }\end{array}$ & No. of CE(s) \\
\hline 0.814939 & 67.62467 & 53.12 & 60.16 & None ** \\
\hline 0.372453 & 36.44791 & 34.91 & 41.07 & At most 1* \\
\hline 0.285822 & 14.58382 & 19.96 & 24.60 & At most 2 \\
\hline 0.218648 & 6.168242 & 9.24 & 12.97 & At most 3 \\
\hline $\begin{array}{l}* * *) \\
\text { significance level L.R. test indicates 1 cointegrating } \\
\text { equation(s) at 5\% significance level }\end{array}$ \\
\hline
\end{tabular}

\section{Error Correction Model}

The result from the parsimonious model in Table 3 revealed that the inflation (INF) has a direct and significant relationship with interest rate (INT) at 5 percent level of significance. Money supply (MS) also had significant relationship in determining the level of interest rate (INT) at 10 percent level of significance. The parameters are all rightly signed except the MPR. Inflation rate and monetary policy rate are not significant at current value while money supply is significant with coefficients and t-statistics in bracket as follows; -0.035686 (-0.546255), 0.086912 (-0.494906), -0.093726 (-1.833847). However, the lags of inflation rate are significant at 1 percent and 5 percent. The determinant of correlation ( $R$ square) revealed that 82 percent changes in interest rate in India are explained by the explanatory variables in the model, while the ECM was rightly signed with 65 percent recovery rate. The probabilities of the $f$ statistics also show that the entire regression model is fit.

Table 3: Error Correction Model

\begin{tabular}{|l|l|l|l|l|}
\hline Variable & $\begin{array}{l}\text { Coeffici } \\
\text { ent }\end{array}$ & $\begin{array}{l}\text { Std. } \\
\text { Error }\end{array}$ & t-Statistic & Prob. \\
\hline C & 0.011828 & 0.038445 & 0.307669 & 0.7646 \\
\hline D(INF) & -0.035686 & 0.065329 & -0.546255 & 0.5969 \\
\hline$D(I N F(-1)$ & 0.137761 & 0.073546 & 1.873124 & $0.0905^{*}$ \\
\hline D(INF(-2) & -0.206174 & 0.077546 & -2.658726 & $0.0240^{* *}$ \\
\hline D(INF(-3) & 0.090992 & 0.062261 & 1.461470 & 0.1746 \\
\hline D(MPR) & -0.086912 & 0.175613 & -0.494906 & 0.6314 \\
\hline D(MPR(-1)) & 0.223574 & 0.143516 & 1.557829 & 0.1503 \\
\hline D(MPR(-2)) & 0.187194 & 0.181698 & 1.030244 & 0.3272 \\
\hline$D(M P R(-3))$ & 0.268676 & 0.156604 & 1.715635 & 0.1170 \\
\hline D(MS) & -0.093726 & 0.051109 & -1.833847 & $0.0966^{*}$ \\
\hline D(MS(-2)) & 0.034794 & 0.053250 & 0.653410 & 0.5282 \\
\hline D(MS(-3)) & 0.043537 & 0.050966 & 0.854222 & 0.4130 \\
\hline ECM(-1) & -0.651367 & 0.245276 & -2.655647 & $0.0241^{* *}$ \\
\hline R-squared & 0.815129 & Mean dependent var & -0.020331 \\
\hline $\begin{array}{l}\text { Adjusted } \\
\text { R-squared }\end{array}$ & 0.593283 & S.D. dependent var & 0.210329 \\
\hline
\end{tabular}




\begin{tabular}{|llll|}
\hline $\begin{array}{l}\text { S.E. of } \\
\text { regression }\end{array}$ & 0.134136 & Akaike info criterion & -0.882398 \\
\hline $\begin{array}{l}\text { Sum } \\
\text { squared } \\
\text { resid }\end{array}$ & 0.179925 & Schwarz criterion & -0.240597 \\
\hline $\begin{array}{l}\text { Log like } \\
\text { lihood }\end{array}$ & 23.14758 & F-statistic & 3.674306 \\
\hline $\begin{array}{l}\text { Durbin- } \\
\text { Watson } \\
\text { stat }\end{array}$ & 1.423969 & Prob(F-statistic) & 0.023807 \\
\hline
\end{tabular}

** denotes rejection of the hypothesis at the 0.05 level

* denotes rejection of the hypothesis at the 0.10 level

\section{Granger Causality Test}

Table 4: Pairwise Granger Causality Tests

\begin{tabular}{|l|c|l|l|}
\hline Null Hypothesis: & Obs & $\begin{array}{l}\text { F-Stati } \\
\text { stic }\end{array}$ & $\begin{array}{l}\text { Proba } \\
\text { bility }\end{array}$ \\
\hline $\begin{array}{l}\text { LNINF does not Granger } \\
\text { Cause LNINT }\end{array}$ & 25 & 1.13911 & 0.37828 \\
\hline $\begin{array}{l}\text { LNINT does not Granger } \\
\text { Cause LNINF }\end{array}$ & & 3.24351 & 0.04430 \\
\hline $\begin{array}{l}\text { LNMS does not Granger } \\
\text { Cause LNINT }\end{array}$ & 25 & 0.88850 & 0.49611 \\
\hline $\begin{array}{l}\text { LNINT does not Granger } \\
\text { Cause LNMS }\end{array}$ & & 0.51578 & 0.72548 \\
\hline $\begin{array}{l}\text { LNMPR does not Granger } \\
\text { Cause NINT }\end{array}$ & 25 & 4.11169 & 0.02078 \\
\hline $\begin{array}{l}\text { LNINT does not Granger } \\
\text { Cause LNMPR }\end{array}$ & 25 & 0.84111 & 0.52179 \\
\hline $\begin{array}{l}\text { LNMS does not Granger } \\
\text { Cause LNINF }\end{array}$ & 25 & 0.78219 & 0.55525 \\
\hline $\begin{array}{l}\text { LNINF does not Granger } \\
\text { Cause LNMS }\end{array}$ & 0.53109 & 0.71503 \\
\hline $\begin{array}{l}\text { LNMPR does not Granger } \\
\text { Cause NINF }\end{array}$ & 25 & 1.36189 & 0.29665 \\
\hline $\begin{array}{l}\text { LNINF does not Granger } \\
\text { Cause LNMPR }\end{array}$ & & 0.88326 & 0.49890 \\
\hline $\begin{array}{l}\text { LNMPR does not Granger } \\
\text { Cause NMS }\end{array}$ & 25 & 0.78179 \\
\hline $\begin{array}{l}\text { LNMS does not Granger } \\
\text { Cause LNMPR }\end{array}$ & & 0.28282 \\
\hline
\end{tabular}

The Granger causality analysis presented in Table 4 showed that at $5 \%$ significance level that most of the variables do not cause each other under pairwise Granger Causality test that is there was no bidirectional causal relationship. Rather, there were two case of unidirectional causality between two variables running from interest rate (LNINT) to inflation rate (LNINF) and from Monetary Policy Rate (LNMPR) to interest rate (LNINT).

\section{CONCLUSION}

This study on the determinants of interest rate under deregulated period in India employed secondary data which was analyzed and tested using ordinary least square multiple regression technique. Based on the regression result it was discovered that there existed a significant relationship between INT and INF, MS. Based on this, the following recommendations were made:

Interest rate is important in forecasting the trend in the growth of the economy in view of the relationships between interest rates explanatory variables which in turn determines economic growth. Thus, the formulation and implementation of financial policies that enhance investment-friendly rate of interest is necessary for promoting economic growth in India.

Complimentary policies such as industrial incentives (tax relief and provision of basic infrastructural facilities) to cushion out the effect of interest rate liberalization on industrial operations are desirable. This will help foster industrial development and economic development.

\section{REFERENCES}

1. Adebiyi, M.A. (2001). "Can High Real Interest Rate Promote Economic Growth without fuelling Inflation in Nigeria?" Journal of Economics and Social Studies, Maiden Edition, Pp. 86- 100.

2. Adebiyi M. A. \&Babatope-Obasa, B. (2004), Institutional Framework, Interest Rate Policy and 
the Financing of the Nigerian manufacturing Sub -Sector. Africa Development and Poverty Reduction: The Macro-Micro linkage, forum paper 13-15 october 2004, Lord Charles Hotel, Somerset West, South Africa.

3. Ahuja, H.L. (2013). "Modern Economics", S. Chand Higher Academic, 17th Revised Edition CBN (2005). Statistical Bulletin. Abuja, Nigeria: Central Bank of Nigeria. CBN (2006). Statistical Bulletin. Abuja, Nigeria: Central Bank of Nigeria.

4. Chris O. U. \&Anyingang R. A, The Effect of Interest Rate Fluctuation on the Economic Growth of Nigeria, 1970-2010 International Journal of Business and Social Science Vol. 3 No. 20 (Special Issue - October 2012)

5. Dlamini, A., A. Dlamini and T. Nxumalo (2001), "A Cointegration Analysis of the Determinants of Inflation in Swaziland", (November).

6. Gul, E. and A. Ekinci (2006), "The Causal Relationship between Nominal Interest Rates and Inflation:

7. The Case of Turkey", Scientific Journal of Administrative Development, Vol. 4, 54 -69.

8. Jhingan M.L. (1990) "Monetary theory" 10th revised edition Vrinda Publications (P) Itd, Delhi India. McKinnon, R. (1973). Money and Capital in Economic Development. The Brookings Institution,Washington D.C.
9. Obute C. Asor A. \&ldoko I. (2012). An assessment of the Impact of Interest Rate Deregulation on Economic Growth in Nigeria 1964-2009, Journal of Business and Organizational Development, ISSN 2277-0070

10. Okechuku, O. \& Adoghor, G. (1999) "Econometrics: An introduction to ordinary least square regression analysis. Springfield Publishers, Owerri Imo State.

11. Omole, A. And Falokun, G. (1999). The impact of interest rate liberalization on the corporate financing strategies of quoted companies in Nigeria. AERC.

12. Shaw, E. (1973). Financial Deepening in Economic Development. Oxford University Press, London. Oresotu,F.O. (1992). "Interest Rate Behavior Under a Programme of Financial Reform: the NigeriaCase". Central Bank of Nigeria (CBN) Economic and Financial Review. 30(2), pp109118.

13. Tayor, T (2004). Determinants of growth?. Retrieved on July 15, 2011 from http:// books.google.co.uk/books 